\title{
Determination of phytocomponents and validation of squalene in ethanolic extract of Clerodendrum serratum Linn roots-using gas chromatography-mass spectroscopy and GC-FID technique
}

\author{
Kalyani Reddy, Gurupadayya B M *, Lodoe Choezom and Hemanth Vikram P R
}

\begin{abstract}
Background: Clerodendrum serratum Linn commonly known as Bharangi in India has wide applications in the Ayurveda and Siddha system of medicine which has been attributed to the treatment of various diseases like asthma, cough, fever, rheumatism, and cephalalgia ophthalmia. Squalene has nutritional, medicinal, and pharmaceutical health benefits, hence possess antioxidant and cytoprotective effects.

Method: The study presents the GC-MS analysis of phytoconstituents present in the Clerodendrum serratum roots and further estimation of one of the constituents, i.e., squalene which is ought to be present in the roots as per mass spectral data obtained. Squalene was determined from the ethanolic extract of C. serratum roots using GC-FID without derivatization.

Results: Four major constituents, i.e., squalene, methyl palmitate, hexadecenoic acid, and stigmasterol were detected by GC-MS. Squalene from the extract was eluted at $17.5 \mathrm{~min}$ which was confirmed with the standard squalene peak eluted at the same retention time. The linearity range chosen was $5-30 \mathrm{ug} / \mathrm{mL}$, and the method was found to be pretty linear $(R=0.995)$, accurate with satisfactory repeatability. Hence, the phytochemical compounds were detected by GC-MS and the squalene was determined and validated according to the ICH guidelines.

Conclusion: Thus, the green gas chromatographic method can be used for quantification and qualification of active constituents in the roots of ethanolic extract of $C$. serratum. In addition, the presence of metabolite squalene by the GC-FID method was developed for the extract which is simple, fast, and environmentally friendly.
\end{abstract}

Keywords: Clerodendrum serratum, Phytoconstituents, GC-MS, Squalene, GC-FID

\footnotetext{
* Correspondence: bmgurupadayya@jssuni.edu.in

Department of Pharmaceutical Chemistry, JSS College of Pharmacy, JSS

Academy of Higher Education \& Research, Mysuru, India 570015
}

(c) The Author(s). 2021 Open Access This article is licensed under a Creative Commons Attribution 4.0 International License which permits use, sharing, adaptation, distribution and reproduction in any medium or format, as long as you give appropriate credit to the original author(s) and the source, provide a link to the Creative Commons licence, and indicate if changes were made. The images or other third party material in this article are included in the article's Creative Commons licence, unless indicated otherwise in a credit line to the material. If material is not included in the article's Creative Commons licence and your intended use is not permitted by statutory regulation or exceeds the permitted use, you will need to obtain permission directly from the copyright holder. To view a copy of this licence, visit http://creativecommons.org/licenses/by/4.0/. 


\section{Introduction}

Clerodendrum serratum Linn commonly known as Bharangi in India has wide applications in the Ayurveda and Siddha systems of medicine. The root and leaf of the plant are attributed in the treatment of various diseases like asthma, cough, fever, rheumatism, and cephalalgia ophthalmia (Bhujbal et al. 2010; Narayanan et al. 1999).

The root is bitter, pungent, acrid, dry, used as digestive, carminative, anti-inflammatory, anti-asthmatic, antispasmodic, anthelmintic, expectorant, appetizer, and stimulant (Patel et al. 2014; Kar et al. 2014). Icosahydropicenic acid, $\beta$-stigmasterol, D-mannitol, octadecenoic acid, hispidulin, and $\gamma$-sitosterol are some of the chief constituents reported to be present in the roots (Kumar and Nishteswar 2013; Mahajan et al. 2019).

Squalene is a linear triterpene having a hydrocarbon chain of six isoprene units which is chemically 2,6,10,15,19,23-hexamethyl-6,6,10,14,18,20-tetracosa-

hexane (Fig. 1), with a $\mathrm{C}_{30} \mathrm{H}_{50}$ molecular formula showing solubility only in organic solvents (Popa et al. 2015; Lozano-Grande et al. 2018). Squalene is synthesized by many plants, animals, bacteria, and fungi that act as an intermediate for the synthesis of secondary metabolites which include hormones, sterols, and vitamins like K, E, and D (Kim and Karadeniz 2012). Several studies have confirmed that squalene showed nutritional, medicinal, and pharmaceutical health benefits (Das et al. 2003). It has been extensively studied and has been reported to possess beneficial bioactivities including antioxidant, cytoprotective effects, and mainly as antitumor, hence suggested for supplementation which may be responsible for tumor growth inhibition and the prevention of normal cells from mutating into tumor cells when exposed to oxidative stress (Kohno et al. 1995; Murakoshi et al. 1992; Amarowicz 2009). Squalene has sparked interest since it was found in shark liver oil, which has been used as conventional medicine for decades (Gershbein and Singh 1969). Squalene is found in the human body, where it is produced by the sebaceous glands to protect the skin and makes up 10$15 \%$ of lipids on the skin surface in concentrations of 300-500 g/g, and less than $75 \mathrm{~g} / \mathrm{g}$ in internal organs including the liver and small intestine (Reddy and Couvreur 2009; Tsimidou 2010; Liu et al. 1976).

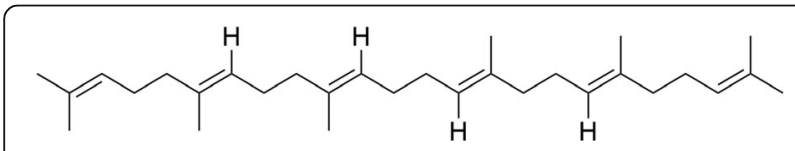

Fig. 1 Structure of squalene
Table 1 GC-MS chromatographic conditions

\begin{tabular}{|c|c|}
\hline Parameters & Instrumental conditions \\
\hline Instruments & $\begin{array}{l}\text { Pekin Elmer Gas Chromatograph Clarus } 680 \text { and } \\
\text { Pekin Elmer Mass Spectrometer Clarus SQ 8C }\end{array}$ \\
\hline Column & $\begin{array}{l}\text { PekinElmer, Elite- } 5 \mathrm{MS} \text { (column } 30 \mathrm{~m} \times 0.250 \mathrm{~mm} \text { I.D. } \\
\times 1 \mu \mathrm{m})\left(60-350^{\circ} \mathrm{C}\right)\end{array}$ \\
\hline Carrier gas & Helium \\
\hline $\begin{array}{l}\text { Oven } \\
\text { temperature }\end{array}$ & $\begin{array}{l}\text { Initial temperature at } 80^{\circ} \mathrm{C} \text { and initial hold for } \\
2.00 \mathrm{~min} \\
\text { Ramp 1: } 10.0 / \mathrm{min} \text { to } 150^{\circ} \mathrm{C} \text {, hold for } 1.00 \mathrm{~min} \\
\text { Ramp 2: } 15.0 / \mathrm{min} \text { to } 250^{\circ} \mathrm{C} \text {, hold for } 10.00 \mathrm{~min}\end{array}$ \\
\hline Total run time & $26.6 \mathrm{~min}$ \\
\hline Split ratio & $10: 1$ \\
\hline Injection vol & $2 \mu l$ \\
\hline $\begin{array}{l}\text { Ionization } \\
\text { technique }\end{array}$ & Electron impact ionization \\
\hline Mass analyzer & Triple quadrupole analyzer \\
\hline
\end{tabular}

Nonetheless, in the next decade, squalene will be a widely used adjuvant in vaccines, creating a new and unparalleled environment in the pharmaceutical industry. As a result, it is important to investigate alternative plant sources, creative techniques that ensure quality and yield, and, above all, the growth of commercial-scale crops that ensure squalene production to fulfill global demand.

GC-MS is the best technique for examining biologically active constituents, such as alcohols, as well as branched-chain hydrocarbons and esters (Sun et al. 1997). As a raw material for cosmetics and pharmaceuticals, squalene must be of high quality and purity, which is determined by extraction and analytical

Table 2 Chromatographic conditions

\begin{tabular}{ll}
\hline Parameters & Values \\
\hline Column temperature & $280^{\circ} \mathrm{C}$ (ZB-Drug-1 column) \\
Detector temperature & $290^{\circ} \mathrm{C}$ \\
Sampling time & $1 \mathrm{~min}$ \\
Run time & $19.7 \mathrm{~min}$ \\
Flow control mode & Linear velocity \\
Pressure & $125.3 \mathrm{kPa}$ \\
Total flow & $12.7 \mathrm{~mL} / \mathrm{min}$ \\
Linear velocity & $29.8 \mathrm{~cm} / \mathrm{s}$ \\
Purge flow & $3.0 \mathrm{~mL} / \mathrm{min}$ \\
Split ratio & $1: 10$ \\
Carrier gas & Nitrogen \\
Detector & Flame ionization detector (FID) \\
Injection volume & $1 \mu \mathrm{l}$ \\
\hline
\end{tabular}




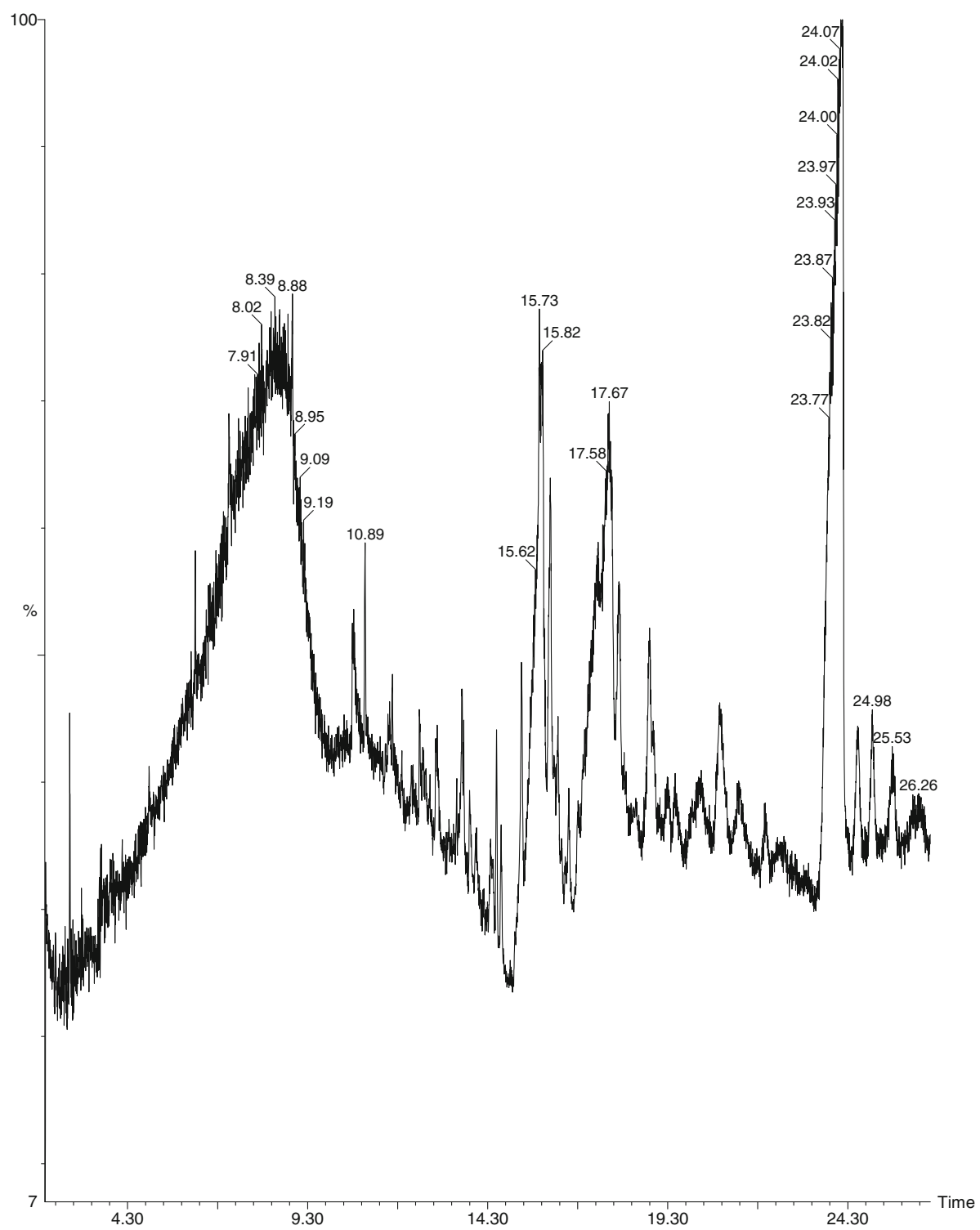

Fig. 2 Chromatogram of ethanolic extract of Clerodendrum serratum roots

techniques. The most commonly used methods for the analysis are gas chromatography (GC) and highresolution liquid chromatography (HPLC) to determine the occurrence of squalene in the hydrocarbon fraction of olive oil derived from the Spanish region of Extremadura; alkanes, alkenes, and sesquiterpenes were quantified in olive oil samples using this method (Bueno et al. 2005).

The objective of this study was to detect the phytochemicals present in the ethanolic extract of Clerodendrum serratum roots using GC-MS and further concentrated on determining squalene which was identified from the GC-MS data using GC-FID detector.

\section{Methods}

\section{Collection of plant material}

The roots of Clerodendrum serratum were collected from the local market located in Mysore.

\section{Authentication of a plant material}

The plant material Clerodendrum serratum was collected and authenticated by Dr. J Suresh, Professor, Department of Pharmacognosy, JSS College of Pharmacy, JSS AHER, Mysore, India (JSSCP/PCOG/17).

\section{Preparation of extract}

The roots of $C$. serratum were washed well and shade dried for 5 days. Then ground to a coarse powder 
A

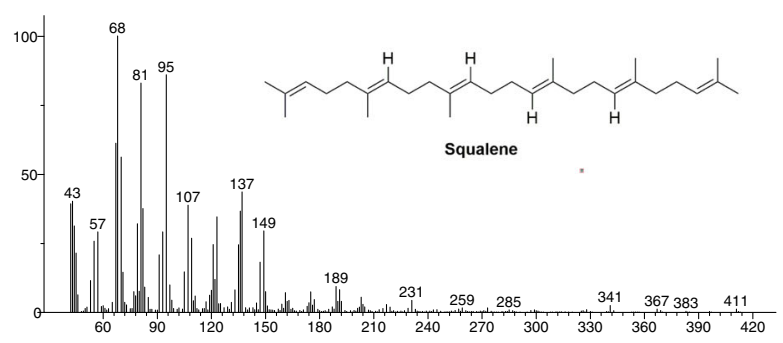

C

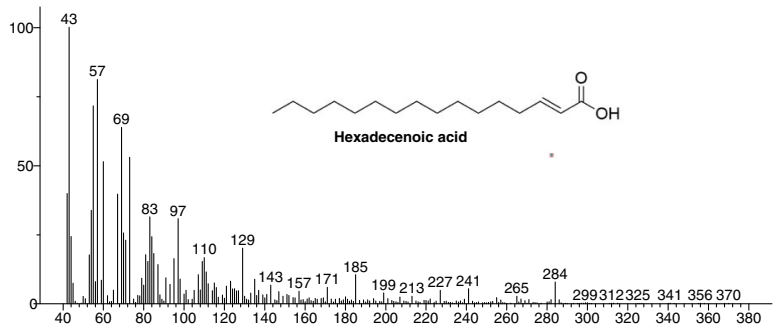

B

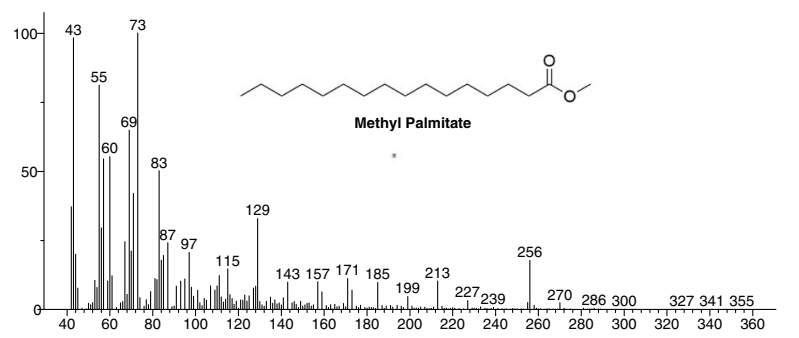

D

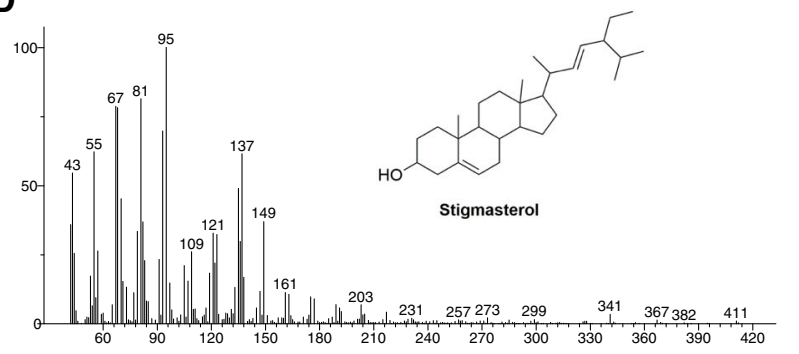

Fig. 3 Mass spectrum of identified compounds

using a mechanical mixer which was further used for the extraction process. The powder was extracted using $99.8 \%$ ethanol solvent. About $50 \mathrm{~g}$ of powder was weighed accurately, packed in filter paper, and placed in a thimble of Soxhlet apparatus attached with a round bottom flask containing a 500-mL ethanol solvent. The Soxhlet set-up was kept on a heating mantle set at an ethanol boiling point temperature, i.e., $72^{\circ} \mathrm{C}$. The extraction was run for 1 day. Then, the extract was filtered under vacuum using a muslin cloth. The filtrate collected was kept in a rotary evaporator wherein, which continued till the ethanol gets completely evaporated and the powdery solid residue which was obtained refrigerated for further use.

\section{GC-MS analysis of ethanolic extract of Clerodendrum serratum roots}

The ethanolic extract obtained from Clerodendrum serratum root plants was subjected to gas chromatography and mass spectroscopy for the determination of phytocomponents. The instruments used and their conditions are discussed below and summarized in Table 1 .

GC-MS was performed for the ethanol extract of $C$. serratum roots to determine the phytochemical compounds. This technique was performed at Chromatogen Analytical Solution Laboratory, Mysore, Karnataka. The instruments used were PekinElmer Gas Chromatograph Clarus 680 with an Elite-5MS column $(30 \mathrm{~m} \times 0.250$ mm I.D. $\times 1 \mu \mathrm{m})$ and Pekin Elmer Mass Spectrometer Clarus SQ 8C. Helium was used as a mobile phase wherein, temperature programming set with an initial temperature of $80^{\circ} \mathrm{C}$ for $2 \mathrm{~min}$, then the temperature raised to $150^{\circ} \mathrm{C}$ with a $10^{\circ} \mathrm{C} / \mathrm{min}$ ramp rate and hold for $1 \mathrm{~min}$, then the temperature was further increased to $250^{\circ} \mathrm{C}$ with a ramp rate of $15^{\circ} \mathrm{C} / \mathrm{min}$ and retained for 10 min; hence, a total run time of sample obtained was 27 min. About $2 \mu \mathrm{l}$ sample was injected with a split ratio of 10:1. Mass spectra were recorded over 35-650 amu range with electron impact ionization energy $70 \mathrm{eV}$. The elucidation of the GC-MS mass range was made utilizing the National Institute of Standards and Technology (NIST) database, which has over 62,000 models. The range of the obscure segment was contrasted with the range of standard components put away in the NIST library. The name, molecular weight, and structure of the components of the test materials have been established.

\section{Validation of squalene in ethanolic extract of Clerodendrum serratum by GC-FID technique Materials}

Squalene was purchased from RL Fine Chem Pvt. Ltd., Bangalore, and HPLC analytical grade methanol was procured from specialties private limited, Mumbai, India.

\section{Instrumentation and chromatographic conditions}

Shimadzu 2014 prototype gas chromatographic system with FID-operated GC solution software and was used for the method development. A 10- $\mu$ l syringe specimen applicator and Zebron DB Column (length $30 \mathrm{~m}$, diameter 0.25 


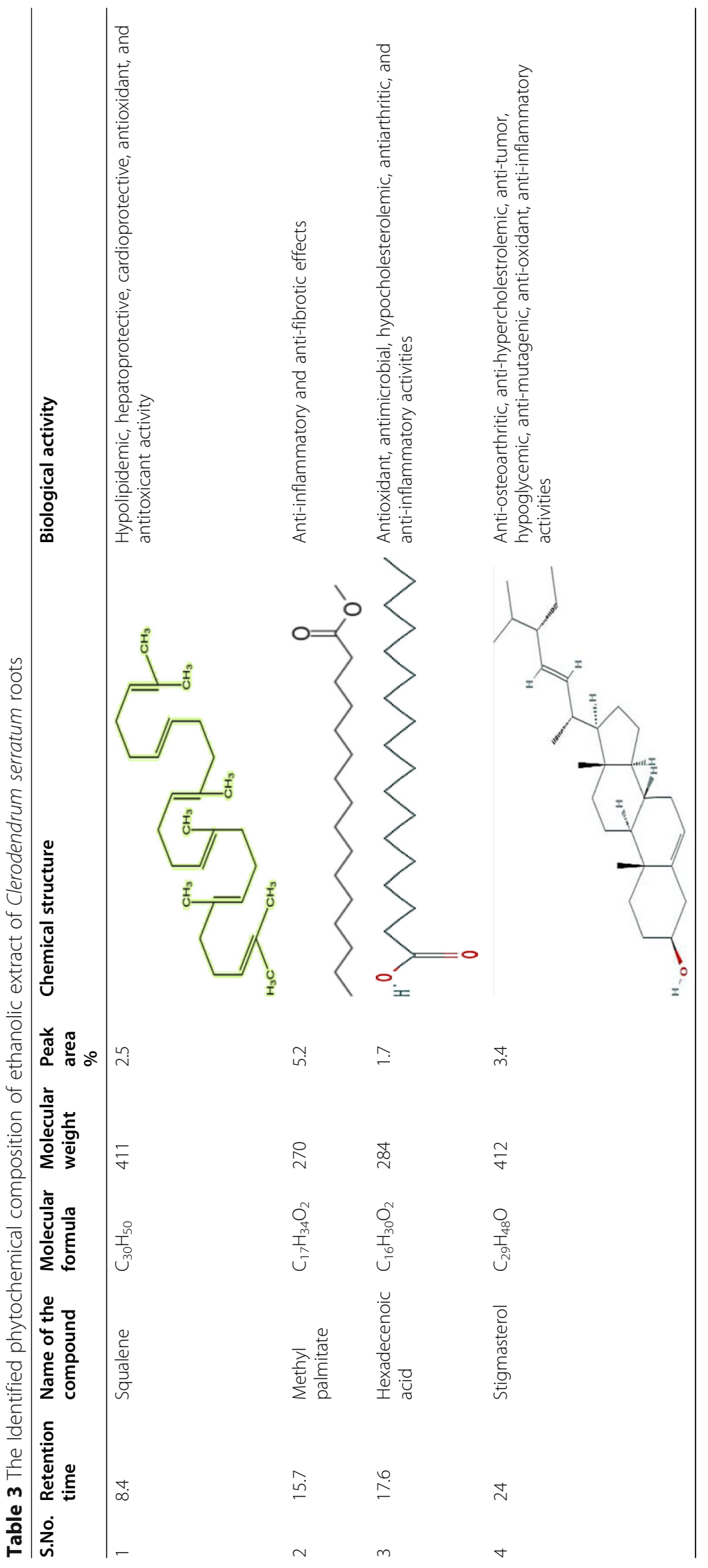


Table 4 GC validation report for the determination of squalene

\begin{tabular}{ll}
\hline Parameter & Value \\
\hline Linearity & $5-30 \mu \mathrm{g} / \mathrm{mL}$ \\
LoD & $0.79 \mu \mathrm{g} / \mathrm{mL}$ \\
LoQ & $1.89 \mu \mathrm{g} / \mathrm{mL}$ \\
Recovery (\%) & $99.85 \%$ \\
Regression coefficient & 0.995 \\
Retention time & $17.5 \mathrm{~min}$ \\
\hline
\end{tabular}

$\mathrm{mm}$, and film $0.50 \mu \mathrm{m}$ ) have been used. Table 2 represents the chromatographic conditions used in the method development of squalene.

\section{Sample preparation}

A 10mg of prepared ethanolic extract was accurately weighed and transferred to a $10-\mathrm{mL}$ volumetric flask made up to the mark using methanol as a diluent solvent $(1000 \mu \mathrm{g} / \mathrm{mL})$. A $100 \mu \mathrm{g} / \mathrm{mL}$ stock solution was prepared by taking $1 \mathrm{~mL}$ from the above-prepared solution and transferred to a $10-\mathrm{mL}$ volumetric flask and made up to the mark using methanol.

\section{Standard squalene solution}

Std squalene stock soln was prepared by accurately measuring $0.01 \mathrm{~mL}$ (equivalent to $10 \mathrm{mg}$ ) std squalene using a micropipette and transferred to a $100-\mathrm{mL}$ volumetric flask, made up to mark by adding methanol diluent to get $100 \mu \mathrm{g} / \mathrm{mL}$ concentration. From which $0.5,1,1.5,2,2.5$, and $3 \mathrm{~mL}$ were pipetted into 6 different $10-\mathrm{mL}$ volumetric flasks, made up to volume using methanol solvent to get $5,10,15,20,25$, and $30 \mu \mathrm{g} / \mathrm{mL}$ concentrations and finally sonicated for 2 min to remove the entrapped air.

\section{Results and discussion}

\section{GC-MS analysis of ethanol extract of Clerodendrum} serratum roots

GC-MS is an ideal technique for the analysis of volatile components, hence frequently used for the resolution of plant samples wherein molecular formula, chemical structure, and functional group prediction are possible from the GC-MS data.

Analysis of ethanolic extract of Clerodendron serratum roots by GC-MS revealed the presence of four major components as shown in Figs. 2 and 3. From the chromatogram and mass spectra, the compounds were identified to be squalene, palmitic acid, hexadecenoic acid, and stigmasterol. The phytochemical composition of the ethanol extract of C. serratum roots with compound name, molecular formula, molecular structure, retention time, and biological activity are shown in Table 3.

Squalene is a triterpenoid that was detected at retention time $8.4 \mathrm{~min}$ with a peak area of $2.5 \%$ revealed to possess hepatoprotective, hypolipidemic cardioprotective, antioxidant, and antioxidant activity (Ghimire et al. 2016). Methyl palmitate was identified at a retention time of $15.7 \mathrm{~min}$, and a peak area of $5.2 \%$ was reported to possess anti-inflammatory and anti-fibrotic effects (El-Demerdash 2011). Hexadecenoic acid which is a long-chain saturated fatty acid was identified at 17.6 min with a peak area of $1.7 \%$. The compound n-hexadecenoic acid was found in Pterocarpus angolensis (Mustapha and Runner 2016). Antimicrobial, antioxidant, hypocholesterolemic, antiarthritic, and anti-inflammatory are some of the pharmacological properties which are reported to be possessed by $n$-hexadecenoic acid. Stigmasterol was identified at 24 min of retention time with a peak area of $3.4 \%$ wherein, and the Wulzen anti-stiffness factor is another term for stigmasterol, which is a form of unsaturated plant sterol. It is one of the potential cholesterols lowering activity and anti-osteoarthritic properties (Gabay et al. 2010). Stigmasterol has antimutagen, antioxidant, and anti-inflammatory properties, as well as inhibiting 24 $\Delta$ reductase, which regulates cholesterol biosynthesis (Rosa et al. 2006).

\section{Validation of squalene in ethanolic extract of clerodendrum serratum by GC-FID technique Method development}

This study aims to develop a simple, robust, and derivatization-free analytical technique for the analysis

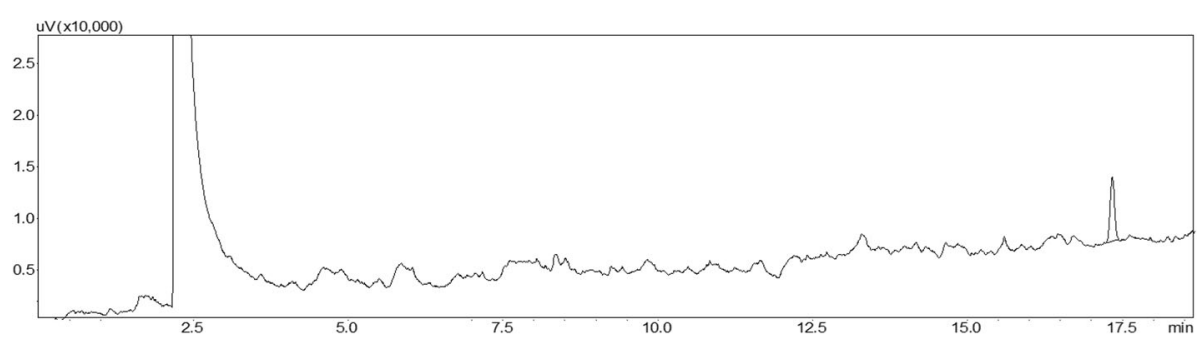

Fig. 4 Chromatogram of squalene in ethanolic extract of Clerodendrum serratum roots 
Linearity curve of Squalene

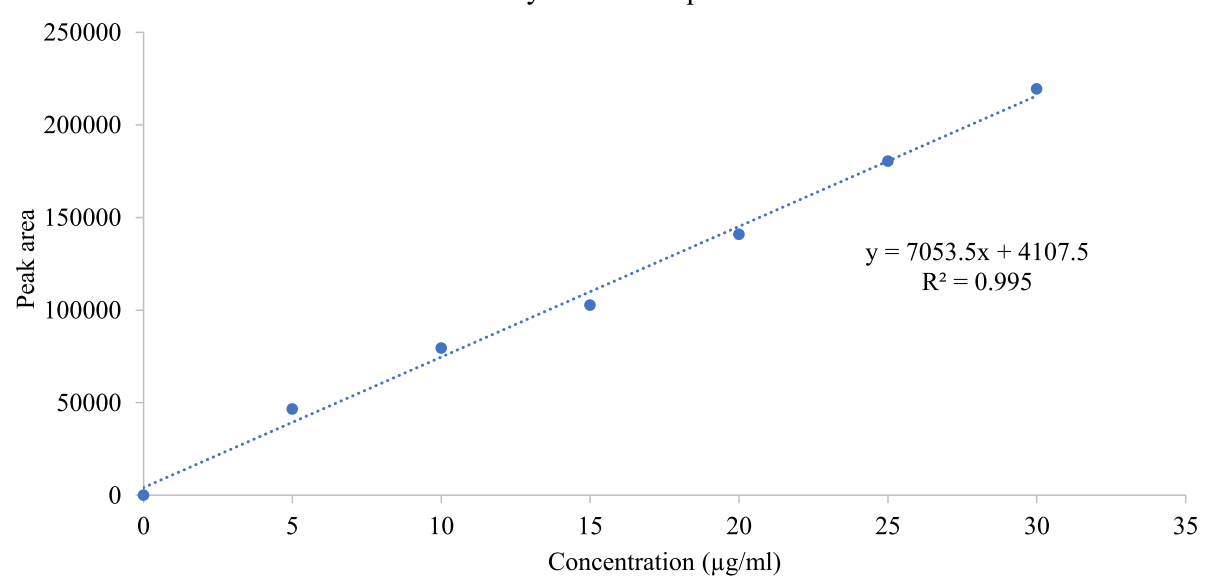

Fig. 5 Linearity graph of squalene

of squalene in ethanolic extract of Clerodendrum serratum roots. To analyze squalene parameters like a solvent, sample size, inlet temperature, column temperature, and program, detector temperature and the pressure were optimized and developed a satisfactory method.

\section{Sample solvent selection}

Sample solvent selection was the first step in developing the GC method wherein, the solvent was decided based on better solubility, ability to produce a good peak shape of the desired component. Hence, initially, ethanol was chosen where the extract was dissolved but resulted in a broad peak. The solubility and peak shape were improved when methanol was used as a sample diluent. Therefore, methanol was selected as a sample solvent.

\section{Sample concentration selection}

The initial trial was conducted using a $1 \mu \mathrm{g} / \mathrm{mL}$ sample but resulted in a very low-intensity peak. Hence, the second trial was conducted using $10 \mu \mathrm{g} / \mathrm{mL}$ and showed a good peak but with low intensity. While good peak was obtained when injected with $100 \mu \mathrm{g} / \mathrm{mL}$ concentration, whereas further injection with $200 \mu \mathrm{g} / \mathrm{mL}$ resulted

Table $\mathbf{5}$ Linearity of squalene

\begin{tabular}{ll}
\hline Concentration $(\boldsymbol{\mu g} / \mathrm{mL})$ & Peak area \\
\hline 5 & 46,521 \\
10 & 80,433 \\
15 & 102,726 \\
20 & 140,845 \\
25 & 180,412 \\
30 & 219,431 \\
\hline
\end{tabular}

in residual carry-over. Therefore, $100 \mu \mathrm{g} / \mathrm{mL}$ was the final chosen sample concentration.

\section{Column screening}

The stationary phase of column polarity plays a critical role in successful resolution and peak shape. For the improved peak resolution, the stationary phase polarity of the column should match with the polarity of a sample selected for analysis. The initial trial was conducted using polydimethylsiloxane (OV-1) but did not result in desired sample peak. Wherein on using $\mathrm{ZB}$, drug column showed effective results.

\section{Selection of injection parameter}

One microliter of injection under splitless mode was chosen to avoid the overloading of a column and also to increase the sensitivity of the method. The injection temperature was chosen based on the boiling point of the squalene, i.e., $275^{\circ} \mathrm{C}$. Hence, to evaporate the sample and generate a good peak, $250^{\circ} \mathrm{C}$ was selected as injection temperature.

\section{Column temperature programming}

The preliminary study of column temperature programming was conducted by taking $150^{\circ} \mathrm{C}$ as an initial temperature, which further raised to $250^{\circ} \mathrm{C}$ with a ramp rate of $15^{\circ} \mathrm{C} / \mathrm{min}$ and retained for $2 \mathrm{~min}$. Subsequently, the temperature was further increased set up to $280^{\circ} \mathrm{C}$ of $3^{\circ} \mathrm{C} / \mathrm{min}$ with a hold time of $2 \mathrm{~min}$. Thus, obtained a total run time of $19.7 \mathrm{~min}$ and the desired peak was eluted at $17.5 \mathrm{~min}$.

\section{Validation}

After establishing the method conditions as described above, the method was validated for linearity accuracy, 


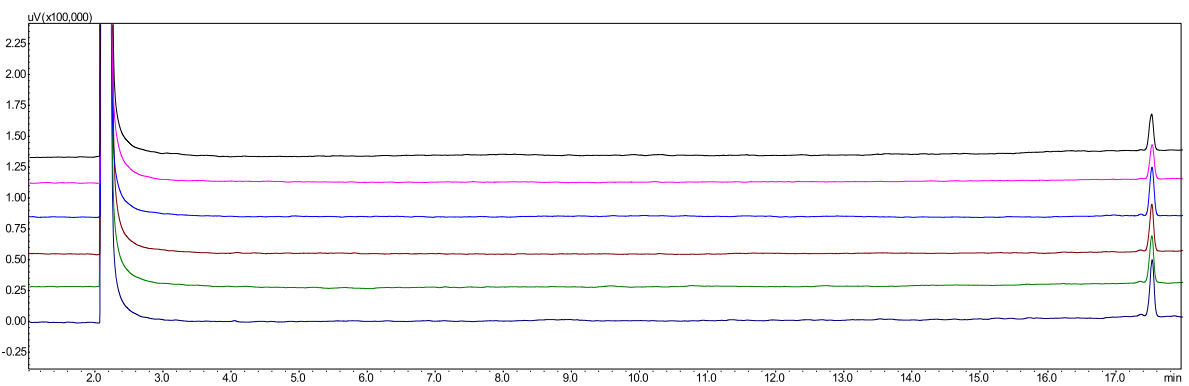

Fig. 6 Overlay chromatogram of standard squalene

precision, the limit of detection, the limit of quantitation, and robustness as per ICH guidelines. The selectivity of the procedure was tested by comparing the retention time of the standard with the desired sample peak of extract, and quantitative analysis of squalene was conducted under the defined conditions. The results of the system suitability are shown in Table 4.

\section{Specificity}

No other interfering peaks were found with the other constituents present in the sample and also on using methanol diluent did not show any interfering peaks, and the retention time of sample peak was confirmed by injecting the sample which showed a peak at the same retention time of that of standard, i.e., at $17.5 \mathrm{~min}$ as shown in Fig. 4.

\section{Assay of squalene in extract}

The developed and validated GC-FID method was used for the quantification of squalene in ethanol extract of C. serratum roots. About $5.5 \mu \mathrm{g}$ of squalene was found to be present in the $100 \mu \mathrm{g} / \mathrm{mL}$ concentration of ethanol extract, which was calculated using the regression coefficient equation from the linearity graph.

\section{Linearity}

The ability to interpret "reports exactly proportional to the sample analyte concentration" is known as linearity. Linearity is important for verifying the system's sensitivity when analyzing analyte concentration within a given range. Linearity was developed by taking serially diluted concentrations range of 5-30 $\mu \mathrm{g} / \mathrm{mL}$. Each dilution was injected and their peak areas were calculated to access method linearity. Squalene linearity graph was plotted by taking peak area versus their concentrations (Fig. 5). The regression coefficient of squalene was found to be 0.995 (Table 5), and Fig. 6 represents the overlay chromatogram of squalene.

\section{Accuracy}

Accuracy refers to how similar a calculated value is to the true value. The percentage recovery method was used to calculate accuracy, which involved spiking a known amount of stock solution into test samples and calculating percentage recovery at three different concentration levels. Three-level (50\%, 100\%, and 150\%) responses of the spiked squalene samples injected were found to be accurate (Table 6). Hence, the results obtained demonstrate that the developed method is having the capability of giving accurate quantification of squalene in ethanolic extract of Clerodendrum serratum roots.

Table 6 Accuracy of squalene

\begin{tabular}{|c|c|c|c|c|c|c|c|}
\hline $\begin{array}{l}\text { Level of } \\
\text { recovery }\end{array}$ & $\begin{array}{l}\text { Amount of sample }(\mu \mathrm{g} / \\
\mathrm{mL})\end{array}$ & $\begin{array}{l}\text { Amount of pure drug } \\
(\mu \mathrm{g} / \mathrm{mL})\end{array}$ & $\begin{array}{l}\text { Total amount of drug } \\
(\mu \mathrm{g} / \mathrm{mL})\end{array}$ & $\begin{array}{l}\text { Peak } \\
\text { area }\end{array}$ & Difference & $\begin{array}{l}\% \\
\text { Recovery }\end{array}$ & $\begin{array}{l}\text { Mean } \\
\%\end{array}$ \\
\hline \multirow[t]{3}{*}{$50 \%$} & 5 & 10 & 15 & 110,252 & 79,720 & 99.113 & \\
\hline & 5 & 10 & 15 & 109,892 & 79,360 & 98.665 & 99.001 \\
\hline & 5 & 10 & 15 & 110,342 & 79,810 & 99.225 & \\
\hline \multirow[t]{3}{*}{$100 \%$} & 5 & 15 & 20 & 130,654 & 100,122 & 97.465 & \\
\hline & 5 & 15 & 20 & 133,402 & 102,870 & 100.14 & 99.248 \\
\hline & 5 & 15 & 20 & 132,822 & 102,290 & 99.575 & \\
\hline \multirow[t]{3}{*}{$150 \%$} & 5 & 25 & 30 & 170,086 & 139,554 & 99.083 & \\
\hline & 5 & 25 & 30 & 171,424 & 140,892 & 100.033 & 99.855 \\
\hline & 5 & 25 & 30 & 172,012 & 141,480 & 100.45 & \\
\hline
\end{tabular}


Table 7 Intra-day precision of squalene

\begin{tabular}{llll}
\hline S. No & $\mathbf{5} \mathbf{\mu g}$ & $\mathbf{1 5} \mathbf{\mu g}$ & $\mathbf{3 0} \mathbf{\mu g}$ \\
\hline 1 & 46,521 & 102,726 & 219,431 \\
2 & 46,873 & 102,442 & 219,722 \\
3 & 46,702 & 101,926 & 220,892 \\
4 & 46,589 & 102,490 & 209,911 \\
5 & 47,212 & 102,314 & 218,324 \\
6 & 45,210 & 105,215 & 218,012 \\
Average & $46,517.83333$ & $102,852.1667$ & $217,715.33$ \\
Standard deviation & 686.648 & 1187.072 & 3960.493 \\
\% RSD & 1.476 & 1.154 & 1.819 \\
\hline
\end{tabular}

\section{Precision}

The degree to which repeated measurements under the same conditions produce the same results is known as a measurement system's precision, which is related to reproducibility and repeatability. The precision was carried out at intra-day and inter-day which was established by injecting 5,15 , and $30 \mathrm{ug} / \mathrm{mL}$ concentration 6 times and \%RSD was calculated. The results were found to be highly precise as the \%RSD shown less than $2 \%$ hence were within the limits according to the ICH guidelines. The results of precision are depicted in Tables 7 and 8 .

\section{LoD and LoQ}

The lowest concentration of an analyte that can be accurately measured but not quantified is known as the LoD while LoQ is the lowest quantity of an analyte that can be quantitatively calculated with defined precision under the stated experimental conditions. The sensitivity of the method was evaluated by LoD and LoQ. Using the equation $\operatorname{LoD}=3.3 \mu / \mathrm{s} \operatorname{LoQ}=10 \sigma / \mathrm{s}$ where $\sigma$ is the standard deviation and $s$ is a slope, the results were obtained, where the LoD was found to be $0.79 \mu \mathrm{g} / \mathrm{mL}$ while $1.89 \mu \mathrm{g} / \mathrm{mL}$ for LoQ of squalene.
Table 8 Inter-day precision of squalene

\begin{tabular}{llll}
\hline S. No & $\mathbf{5} \boldsymbol{\mu g}$ & $\mathbf{1 5} \boldsymbol{\mu g}$ & $\mathbf{3 0} \boldsymbol{\mu g}$ \\
\hline 1 & 45,433 & 103,911 & 218,768 \\
2 & 46,692 & 102,874 & 216,783 \\
3 & 47,235 & 102,921 & 220,453 \\
4 & 46,328 & 103,242 & 214,330 \\
5 & 47,394 & 107,983 & 212,754 \\
6 & 46,989 & 103,872 & 220,765 \\
Average & $46,678.5$ & $104,133.833$ & $217,308.83$ \\
Standard deviation & 720.047 & 1938.443 & 3281.965 \\
\% RSD & 1.542 & 1.861 & 1.5102 \\
\hline
\end{tabular}

\section{Robustness}

Even after making deliberate changes, the results obtained are found to be accurate or within the method's defined tolerance limits, which is known as robustness. It was accessed by changing the operational parameters such as split ratio, column flow rate, and injection. The results obtained on variation in parameters are summarized in Table 9 which showed low variation in values, hence represents that method is robust.

\section{Conclusions}

The GC-MS result of the ethanol extract of $C$. serratum revealed the presence of four major constituents namely squalene, methyl palmitate, hexadecenoic acid, and stigmasterol. It investigates the persistence of essential bioactive constituents with the potential to be used as a drug product in the pharmaceutical industry. This demonstrates that $C$. serratum roots can be used to cure a variety of illnesses and has medicinal value. The developed derivatization-free GC-FID method can be used to determine squalene from $C$. serratum roots. For different concentrations of squalene, the procedure demonstrated linearity. Hence, the process was found to be precise, sensitive, and robust and has strong reproducibility according to the $\mathrm{ICH}$ guidelines.

Table 9 Robustness result for squalene

\begin{tabular}{|c|c|c|c|c|c|}
\hline Condition & & Tailing & Concentration & Peak area & $\%$ RSD \\
\hline \multirow[t]{3}{*}{ Split ratio } & $10: 01$ & 1.383 & $30 \mathrm{ug} / \mathrm{mL}$ & 214023 & 1.219 \\
\hline & $9: 09$ & 1.364 & & 217221 & \\
\hline & $10: 02$ & 1.372 & & 212037 & \\
\hline \multirow[t]{3}{*}{ Column flow rate } & $0.9 \mathrm{~mL} / \mathrm{min}$ & 1.374 & $30 \mathrm{ug} / \mathrm{mL}$ & 218025 & 1.738 \\
\hline & $1.1 \mathrm{~mL} / \mathrm{min}$ & 1.392 & & 216963 & \\
\hline & $1.2 \mathrm{~mL} / \mathrm{min}$ & 1.331 & & 211075 & \\
\hline \multirow[t]{3}{*}{ Injection temperature } & $245^{\circ} \mathrm{C}$ & 1.36 & $30 \mathrm{ug} / \mathrm{mL}$ & 219352 & 1.822 \\
\hline & $248{ }^{\circ} \mathrm{C}$ & 1.353 & & 214210 & \\
\hline & $255^{\circ} \mathrm{C}$ & 1.394 & & 211657 & \\
\hline
\end{tabular}




\section{Abbreviations}

C serratum: Clerodendrum serratum; GC-FID: Gas chromatography with flame ionization detector; GC-MS: Gas chromatography with mass spectrometry; HPLC: High-performance liquid chromatography; ICH: International Council on Harmonisation; ID: Internal diameter; kPa: Kilopascal; LoD: Limit of detection; LoQ: Limit of quantification; RSD: Relative standard deviation

\section{Acknowledgements}

We are grateful to the JSS Academy of Higher Education (JSSAHER) Mysuru, India, for providing all of the facilities needed for the successful completion of research work.

\section{Authors' contributions}

BMG has framed the concept for this work and carried out by KR and HPR The extraction and isolation were supported by HPR and LC. The statistical data and manuscript were framed by all the authors. The author(s) read and approved the final manuscript.

\section{Funding}

This work has not been financially supported

\section{Availability of data and materials}

Not applicable

\section{Declarations}

Ethics approval and consent to participate

Not applicable

\section{Competing interests}

The authors declare that they have no competing interests.

Received: 20 April 2021 Accepted: 20 July 2021

Published online: 03 August 2021

\section{References}

Amarowicz R. Squalene: a natural antioxidant? Eur J Lipid Sci Technol. 2009; 111(5):411-2. https://doi.org/10.1002/ejlt.200900102.

Bhujbal SS, Nanda RK, Deoda RS, Kumar D, Kewatkar SM, More LS, et al. Structure elucidation of a flavonoid glycoside from the roots of Clerodendrum serratum (L.) Moon, Lamiaceae. Rev Bras. 2010;20(6):1001-2. https://doi.org/1 0.1590/S0102-695X2010005000041.

Bueno EO, Casas JS, García AM, González LG. Discriminating power of the hydrocarbon content from virgin olive oil of Extremadura cultivars. J Am Oil Chem Soc. 2005;82(1):1-6. https://doi.org/10.1007/s11746-005-1034-0.

Das B, Yeger H, Baruchel H, Freedman M, Koren G, Baruchel S. In vitro cytoprotective activity of squalene on a bone marrow versus neuroblastoma model of cisplatin-induced toxicity: implications in cancer chemotherapy. Eur J Cancer. 2003;39(17):2556-65. https://doi.org/10.1016/j.ejca.2003.07.002

El-Demerdash E. Anti-inflammatory and antifibrotic effects of methyl palmitate. Toxicol Appl Pharmacol. 2011;254(3):238-44. https://doi.org/10.1016/j.taap.2 011.04.016.

Gabay O, Sanchezyz C, Salvaty C, Chevy F, Breton M, Nourissaty G, et al. Stigmasterol: a phytosterol with potential anti-osteoarthritic properties. Osteoarthr Cartil. 2010;18(1):106-16. https://doi.org/10.1016/j.joca.2009.08.01 9106.

Gershbein LL, Singh EJ. Hydrocarbons of dogfish and cod livers and herring oil. J Am Oil Chem Soc. 1969;46(10):554-7. https://doi.org/10.1007/BF02633182.

Ghimire GP, Nguyen HT, Koirala N, Sohng JK. Advances in biochemistry and microbial production of squalene and its derivatives. J Microbiol Biotechnol. 2016;26(3):441-51. https://doi.org/10.4014/jmb.1510.10039.

Kar P, Goyal AK, Das AP, Sen A. Antioxidant and pharmaceutical potential of Clerodendrum L.: an overview. Int J Green Pharm. 2014;8:210-6. https://doi. org/10.22377/ijgp.v8i4.415

Kim SK, Karadeniz F. Biological importance and applications of squalene and squalane. Adv Food Nutr Res. 2012;65:223-33. https://doi.org/10.1016/B9780-12-416003-3.00014-7.

Kohno Y, Egawa Y, Itoh S, Nagaoka S, Takahashi M, Mukai K. Kinetic study of quenching reaction of singlet oxygen and scavenging reaction of free radical by squalene in n-butanol. Biochim Biophys Acta. 1995;1256(1):52-6. https:// doi.org/10.1016/0005-2760(95)00005-W
Kumar P, Nishteswar K. Phytochemical and pharmacological profiles of Clerodendrum Serratum Linn. (Bharangi): a review. Int J Res Ayurveda Pharm. 2013;4(2):276-8. https://doi.org/10.7897/2277-4343.04239.

Liu GC, Ahrens EH Jr, Schreibman PH, Crouse JR. Measurement of squalene in human tissues and plasma: validation and application. J Lipid Res. 1976;17(1): 38-45. https://doi.org/10.1016/S0022-2275(20)37014-0.

Lozano-Grande MA, Gorinstein S, Espitia-Rangel E, Dávila-Ortiz G, Martínez-Ayala AL. Plant sources, extraction methods, and uses of squalene. Int J Agron. 2018;2018:1-13. https://doi.org/10.1155/2018/1829160.

Mahajan H, Singh Arora D, Singh H, Jain SK, Namarta K, Singh J. Scientific validation of the antimicrobial and antiproliferative potential of Clerodendrum serratum (L.) moon, its phytoconstituents and their biosafety by acute oral toxicity study. Drug Chem Toxicol. 2019;1(4):1-11. https://doi. org/10.3109/13880209109082904.

Murakoshi M, Nishino H, Tokuda H, Iwashima A, Okuzumi J, Kitano H. Inhibition by squalene of the tumor promoting activity of 12-0-tetradecanoylphorbol13-acacetate in mouse skin carcinogenesis. Int J Cancer. 1992;52(6):950-2. https://doi.org/10.1002/ijc.2910520620

Mustapha NA, Runner RTM. GC-MS Analysis and preliminary antimicrobial activity of Albizia adianthifolia (Schumach) and Pterocarpus angolensis (DC). Medicines. 2016;3:3. https://doi.org/10.3390/medicines3010003.

Narayanan N, Thirugnanasambantham P, Viswanathan S, Vijayasekaran V, Sukumar E. Antinociceptive, anti-inflammatory and antipyretic effects of ethanol extract of Clerodendron serratum roots in experimental animals. Ethnopharmacol. 1999;65(3):237-41. https://doi.org/10.1016/S0378-8741 (98)00176-7.

Patel JJ, Acharya SR, Acharya NS. Clerodendrum serratum (L.) Moon. -a review on traditional uses, phytochemistry and pharmacological activities. J Ethnopharmacol. 2014;154(2):268-85. https://doi.org/10.1016/j.jep.2014.03.071

Popa O, Băbeanu NE, Popa I, Niță S, Dinu-Pârvu CE. Methods for obtaining and determination of squalene from natural sources. Biomed Res Int. 2015;2015: 1-16. https://doi.org/10.1155/2015/367202.

Reddy LH, Couvreur P. Squalene: a natural triterpene for use in disease management and therapy. Adv Drug Deliv Rev. 2009;61(15):1412-26. https:// doi.org/10.1016/j.addr.2009.09.005.

Rosa RM, Melecchi Ml, da Costa HR, Abad FC, Simoni CR, Caramão EB, et al. Antioxidant and antimutagenic properties of Hibiscus tiliaceus L. methanolic extract. J Agric Food Chem. 2006;54(19):7324-30. https://doi.org/10.1021/ jf061407b.

Sun H, Wiesenborn D, Tostenson K, Gillespie J, Rayas DP. Fractionation of squalene from amaranth seed oil. J Am Oil Chem Soc. 1997;74(4):413-8. https://doi.org/10.1007/s11746-997-0099-8.

Tsimidou MZ. Chapter 61 Squalene and Tocopherols in Olive Oil. In: Preedy VR, Watson RS, editors. Olives and olive oil in health and disease prevention: Academic Press, Elsevier; 2010. https://doi.org/10.1016/b978-0-12-374420-3. 00061-9.

\section{Publisher's Note}

Springer Nature remains neutral with regard to jurisdictional claims in published maps and institutional affiliations.

\section{Submit your manuscript to a SpringerOpen ${ }^{\circ}$ journal and benefit from:}

- Convenient online submission

- Rigorous peer review

- Open access: articles freely available online

High visibility within the field

- Retaining the copyright to your article

Submit your next manuscript at $>$ springeropen.com 